\title{
Legal Challenges and Pitfalls for Start-up Companies - 48 Common Questions and Answers
}

\author{
Matthias Staehelin*
}

\begin{abstract}
Transforming a business idea into reality requires a legal implementation plan. The following 48 questions and answers address key issues that typically arise in start-up situations. Early planning can help avoid costly mistakes.
\end{abstract}

Keywords: Legal implementation plan · Start-up

\section{General Questions}

Q1. What questions need to be addressed first?

Prior to incorporation the founders need to consider liability issues: each member of the founder team may be liable for the entire debt incurred by the team. Founders also need to consider tax issues including social security, e.g. how salaries are paid. Finally, the founders need to agree on the initial financing, on the company name, on who sits on the board and on who will form the management.

Q2. How long does the formation process take and when is the right time to found a company?

The formation process typically takes one to three weeks. This process should be completed once the founder team starts to incur material liabilities. Furthermore, the foundation should preferably be completed prior to initiating steps towards acquiring assets (e.g. a license agreement); such intentions require additional disclosure at foundation and will trigger additional costs.

Q3. Which legal specialists are needed in the start-up phase?

The key specialist for the foundation process is the notary public who will assist

${ }^{*}$ Correspondence: Dr. M. Staehelin

Attorney at Law and Notary Public VISCHER Ltd

Aeschenvorstadt 4, CH-4010 Basel, Switzerland

Tel.: +41582113353

Mobile: +4179 4357354

E-mail: mstaehelin@vischer.com in drafting the initial articles of association and arrange for the registration in the register of commerce. Additional specialists required in the start-up phase are a bookkeeper responsible for the accounts, an IP attorney for filing any patents/trademarks and a corporate attorney for the initial contracts (shareholders' agreement, employment agreements, etc.).

\section{Q4. Why does the foundation require} a notary public?

The foundation of a company is the 'birth' of the company subject to the registration in the commercial register. For this reason the law requires a formal procedure, namely a foundation declaration in front of a notary. This means that an independent third person examines whether all foundation conditions are met. The process also ensures that the founders do not violate the rules regarding contributing assets or acquiring assets post-foundation from shareholders.

\section{Legal Form}

Q5. How does one form a Company and what legal forms are available?

Swiss law provides for the following legal forms:

- company limited by shares (Aktiengesellschaft / Société Anonyme (AG/SA))

- limited liability company (Gesellschaft mit beschränkter Haftung / Société à responsabilité limitée (GmbH/Sàrl))

- limited partnership (Kommanditgesellschaft / société en commandite)

- general partnership (Kollektivgesellschaft / société en nom collective)

- simple partnership (einfache Gesellschaft / société simple)
The key purpose of company formation is the separation of the founders' business liabilities from their personal assets. Simple partnerships, general partnerships and limited partnerships are not adequate for most start-ups as some or all partners would be exposed to unlimited personal liability. The separation of liabilities is only achieved by establishing either a company limited by shares or a limited liability company. The limitation of personal liability is, however, only guaranteed if the Company is clearly identified as a company limited by shares or limited liability company when dealing with business partners. Most investors insist on a company limited by shares (AG/SA). have?

Q6. What duties do shareholders

In the case of a company limited by shares and a limited liability company the company capital is solely liable for the Company's debts. If a shareholder of a company limited by shares (AG/SA) fulfills his/her obligations to pay up the shares, he/she has fulfilled all his/her duties.

Q7. Why do I need to set up a legal structure early on?

If members of your team are developing intellectual property rights (IP), the lack of a legal structure means that every participant will have individual rights to the IP developed and that its commercialization becomes complicated. A key founder could avoid this situation if all other persons assigned the IP rights to such a key founder. In practice, this kind of assignment is rarely made. Furthermore, it is difficult to get a founder team together without a formal structure. Often members of the team are promised unrealistic specific stakes early on without knowing the 
full picture. Setting up the structure early may avoid such unrealistic promises/expectations. Finally, waiting too long to set up the structure may create tax problems: If founders are paid in shares, then these shares may constitute taxable income; the longer one waits with setting up the structure, the more valuable the shares may become and thus the higher this potential income may be, even though it may still be years before there is enough cash to pay these taxes.

\section{Name \& Trademark}

Q8. How do I find a company name and can I choose any name?

In today's world it is advisable that the company name and the domain name, including the e-mail address, are identical. A number of limitations need to be observed: First, a company name must not be identical to an existing company name. Second, it may not be so similar that confusion could be created with an existing company name. All existing company names can be found online at www.zefix.ch. Third, the chosen name must be true and not misleading (for example 'Cure Ltd.' would not be permissible). Fourth, a company name should take into account existing trademarks, see the Swiss database (www.swissreg.ch) and the European database (https://oami.europa.eu/).

With a fantasy name the founders have the best chance to find both an available URL and company name. Descriptive names are often problematic: the company name 'Life Sciences Ltd' would not be allowed because such a general description cannot be monopolized by one company.

Whenever they use the company name, founders should make sure they always add the 'AG/SA/Ltd' to the name so that business partners are aware that they are dealing with a company limited by shares. It is, however, permitted to omit the legal form in logos and graphic symbols.

Q9. Can a company do business under a name which is different from the company name?

In principal a company must use its business name so that business partners can be sure they are conducting business with the intended legal person. There are a few exceptions to this principle, e.g. a short version of the company name is sometimes permissible in advertising etc., provided there is no risk of confusion.

Q10. What is the difference between a company name and a trademark?

The company name serves to identify the company. In contrast trademarks serve to identify products or services. When choosing the company name, founders should take care not to violate any third party trademarks: Even if the company name 'Rivella AG' were still be available, it must not be used because there is a substantial risk of confusion with the trademark 'Rivella'.

\section{Q11. Do I need trademark protection?}

Trademark protection for a company name is rarely done. However, trademark protection should be sought at an early stage for any goods or services the company intends to deliver.

\section{Foundation with Cash only}

Q12. What is the minimal cash amount to be paid in at foundation?

The establishment of a company limited by shares requires an initial commitment of CHF 100'000 of which at least CHF 50'000 have to be paid into a special foundation account at a Swiss bank at foundation. The outstanding CHF 50'000 can remain unpaid but has to be contributed by the founders once the company calls the money. The unpaid commitment can be declared by the founders as liability in their tax declaration.

In case of a limited liability company the minimum payment at foundation is CHF 20'000.

Q13. What is the process of the foundation with cash?

The company is incorporated by the founders declaring, in a notarized deed, the foundation of the company limited by shares by adopting in the articles of association and by appointing the corporate bodies, namely the board of directors and - if not waived - the auditors. The foundation act includes three confirmations, namely (1) all shares have been validly subscribed, (2) the promised contributions correspond to the total amount of the issued shares and (3) the requirements set forth by both the law and the articles of association concerning the contributions are met. Furthermore, each founder must unconditionally commit to make a contribution equal to the issue price of the shares allocated to, and subscribed by, such founder.

\section{Foundation with Assets}

\section{Q14. How does a foundation without} cash work?

If founders contribute transferable assets in lieu of cash, then there is a risk that the share capital is not covered by real assets. Therefore a number of restrictions apply: First, the assets must be freely transferable, second, the fair market value of such assets must be confirmed by an independent auditor and third, the Company must be able to freely dispose of the assets immediately after foundation. These criteria mean that work results created by the founders can rarely be used.

Q15. What is the process for a foundation with assets?

In the case of a foundation with assets, additional work needs to be performed. First, the founders must prepare a so-called founders' report describing the assets and the adequacy of the valuation and which must include a detailed description of the assets and state how the fair market value has been calculated, including a description of the valuation principles. Second, an auditor must examine the founders' report and confirm in writing that the report is complete and correct. Thus the auditor must also examine the adequacy of the evaluation of the contributed assets. If the founders' report does not reflect the true value of the assets and as a result the company's creditors suffer damages, then the founders may be personally liable.

\section{Foundation with Intent to Acquire Assets (including License)}

Q16. What is the process for a foundation with the intent to acquire an asset/ license etc. post foundation?

In the case of a foundation with the intent to acquire assets or a license in the future from a shareholder or a person related to a shareholder the same transparency rules as for a foundation with assets apply: The founders have to prepare and sign a founders' report describing the intended acquisition together with the maximum acquisition price. Furthermore, an auditor must examine the founders' report and confirm its completeness and correctness.

Q17. Why is it important to disclose certain Company intentions?

If a Company acquires an asset or obtains the license from a founder or a related party, then such transaction must be disclosed at foundation. In the absence of such disclosure the transaction in question may be null and void. This could have the consequence that the Company's key license agreement would not be enforceable and that at the time of exit a potential buyer realizing this risk could drop out.

Q18. What is the Stampa declaration?

The Stampa declaration is a safeguard statement for the register of commerce stating that all non-cash payments of shares or intended acquisitions from founders and related parties have been disclosed. In addition, the declaration includes the state- 
ment that no real estate in Switzerland has been acquired by companies controlled by non-Swiss persons.

\section{Domicile}

\section{Q19. What are the domicile require- ments?}

Typically, a start-up company will rent an office in Switzerland which then serves as registered address. In the absence of an actual office the registered office can be c/o (care of) a private person.

\section{Residence}

Q20. What are the Swiss residence requirements?

There is no requirement that board members are Swiss residents. However, at least on management level at least one Swiss resident with single signatory rights (or two Swiss residents with joint signatory rights) must be registered with the register of commerce at foundation.

\section{Bodies of the Company}

Q21. What are the bodies of the company limited by shares?

The statutory corporate bodies of the company limited by shares are first, the shareholders' meeting; second, the board of directors with at least one member and third, the auditors.

\section{Q22. Do I need an auditor?}

The founders can waive the audit requirement. An audit is only legally required once a company has more than ten employees or crosses certain financial thresholds. An audit is strongly advised once a company accepts financial investors among its shareholders.

\section{Single Founder} pany?

Q23. Can one person found a com-

Yes. One founder is sufficient to establish a company limited by shares or a limited liability company.

\section{Founder Privileges}

Q24. Which tools exist to grant share privileges to founders?

Normally each share has one vote. Registered shares can be issued with privileged voting rights by allocating such shares a lower par value. These privileges may not be more than tenfold meaning that if the nominal value is CHF 1 , the nominal value of the founders' shares with privileged voting rights may not be lower than CHF 0.10.

Q25. What do I need to know about related party transactions?

Any transaction between a company and any of its shareholders or closely connected persons must be transacted at arm's length, meaning on the same economic conditions as for unrelated business partners. Any deviation from this principle causes a number of corporate law and tax issues; in particular any benefit granted to a particular shareholder by the company (e.g. sale of an asset below fair market value by the company to a shareholder) will be treated by the tax authorities as a constructive dividend and may be subject to criminal sanctions. As a matter of corporate governance any transaction with a related party should be resolved by the board of directors and should be approved only by directors who have no conflict of interest in the matter or are not connected with the shareholder or related person in question.

\section{Several Founders/Shareholders' Agreement}

Q26. Which questions do I need to clarify with the co-founders?

The dynamic within a founder team is important. A clear allocation of tasks and expectations is essential in order to keep the founder team intact. The founders need to agree at an early stage on a number of points including what percentage of the founder stock is allocated to which persons, which portion of the founders' shares will be allocated for future work prior to the next financing round and the roles and responsibilities of each founder, what the impact is if a founder leaves the team, and what salaries - if any - are paid to the founders and how key decisions are to be made.

Q27. What are the legal steps in the case of more than one founder?

Swiss corporate law does not provide adequate rules for the relationship between several founders. Therefore, a shareholders' agreement regarding corporate governance and transfer of shares at exit is highly recommended.

\section{Q28. Why are shareholders' agree-} ments concluded?

Swiss corporate law has a general rule that shareholders of an AG/SA cannot be obliged to contribute more than the amount owed for the subscription of shares at foundation or at the occasion of a capital increase. Any additional obligation (e.g. right of first refusal, non-competition, etc.) must be agreed between the shareholders in the form of a separate agreement, the so-called shareholders' agreement. A shareholders' agreement typically regulates the following matters:

- financing

- corporate governance including voting rights

- board representation

- transfer restrictions

- non-compete / non-solicitation

- assignment of IP

- provisions facilitating an exit of the company

\section{Articles of Association}

Q29. Why does a Company need articles of association?

The articles of association are the company's playbook. They regulate the company name, domicile, purpose, capital structure, amount of the share capital, type, number and par value of the shares and the procedural matters for shareholders' meetings, the board and auditors. In addition, they regulate the voting rights and the internal organization of the Company. These articles are binding on all shareholders (contrary to a shareholders' agreement which is only valid between the parties signing such agreement). The articles are a public document and any change requires a notarial deed.

Q30. How to draft the purpose in the articles of association?

The purpose in the articles of association has a particular meaning. It defines the context in which the company's corporate bodies can act. If the company's purpose is 'research and development in life sciences', then trading derivatives for silver or gold falls outside the company's purpose. Such transactions would then probably be invalid. It is advisable not to draft the business purpose too narrowly in order to allow enough room for the company to grow.

\section{Organizational Rules}

\section{Q31. Why are organizational rules} needed?

The organizational rules or regulations are enacted by the board and define the distribution of tasks, competences and responsibilities within the board of directors and the delegation of the day-to-day management to the management personnel. These regulations allocate the tasks management can perform without board approval. Organizational rules may also reflect some of the rules included in the shareholders' agreement and thus trans- 
form those rules agreed between the shareholders into a company document. These rules are an internal document and can be changed by simple board resolution.

\section{Foundation Process}

Q32. Why must a company be registered with the register of commerce?

The registration of the notarial deed at the register of commerce is required so that the company actually gains its legal status. The filing with the register of commerce is typically done by the notary public. The following documents are required for the application:

a) Application to the register of commerce indicating the corporate bodies

b) Notarial Deed

c) Articles of Association

d) Legalized signature/s

e) Founders' report (in case of contributed assets or an intended acquisition of assets)

f) Passport copies of board members and other signatories

g) Stampa Declaration

The application to the commercial register results in an entry being made in the journal of the commercial register. This entry is then forwarded to the federal commercial register which verifies the registration. Once the federal commercial register approves the entry, the entry into the cantonal commercial register becomes final.

\section{Form and Transfer of Shares}

Q33. What are registered shares? What are bearer shares?

Shares of a company limited by shares (AG/GmbH) are either issued in the holders' name (registered shares) or in the bearers' name (bearer shares). Both types of shares can co-exist. A company with bearer share certificates cannot be sure about the identity of its shareholders. Furthermore, if a bearer share certificate gets lost, a complicated procedure taking around 18 months must be initiated in order to issue a replacement. Therefore almost all start-up companies chose to issue registered shares.

\section{Q34. How can I transfer shares?}

In case of registered shares the transfer requires either a written assignment or a written endorsement of the share certificate plus the approval of the board of directors. Bearer shares are transferred by handing over the certificates. Often shareholders' agreements require additional steps e.g. offering all other shareholders the option to buy the shares in priority (right of first refusal).

\section{Taxes}

Q35. What do I need to know about taxes?

A foundation with a capital of less than CHF 1'000'000.- does not trigger any stamp taxes; any capital contribution beyond that amount will trigger a stamp tax of $1 \%$. Most start-ups will benefit if they register the company for VAT purposes even if the required minimal turnover is not yet met as this will allow them to obtain refunds of VAT paid to third party suppliers. As soon as income exceeds expenses, tax planning is essential in view of the profit taxes.

\section{Shell Companies}

Q36. Can I shorten the process by acquiring a shell company?

Purchasing an existing non-operative company (shell company) is risky: First, the purchase of a shell company may be void as the incorporation provisions of Swiss corporate law may not have been complied with. Second, the founders do not know whether the purchased shell has had any activity and may acquire a company with unknown liabilities. Last, acquiring a shell company may trigger tax liabilities. Therefore, the acquisition of a shell company typically ends up with significantly higher costs than the incorporation of a new company.

\section{Intellectual Property (IP)}

Q37. How can I protect the company's intellectual property $(I P)$ ?

As a matter of principle, every person working on company intellectual property (IP) needs to be either an employee with a written employment contract or a consultant with a consulting agreement specifying that all IP developed belongs to the company. Without such arrangements, the company's IP could potentially end up in the wrong hands and render any further financing impossible. It is strongly advisable that the company does not divulge any business secrets (including the description of the business idea and the business plan) to any person who has not signed a confidentiality or non-disclosure agreement.

\section{Q38. What is the right moment to file} a patent?

Many start-ups have intellectual property whose value will largely be reduced or compromised once it is disclosed to the public. In such cases seeing a good patent lawyer is important in order to develop a patent strategy for protecting such IP. Often provisional patent filings are available.
This is especially important if this information needs to be disclosed to potential investors. If early disclosure is important then this should be done incrementally and under the terms of a confidentiality agreement. If a potential investor refuses to sign a confidentiality agreement then he should not receive any confidential information.

\section{Q39. Publish or protect?}

Many companies need to adapt an IP protection strategy in order to ensure that a later patent application is not made impossible by a prior publication.

\section{Employee and Employee Participation}

Q40. Do the founders need employment agreements?

An employment agreement is advisable for any founder who receives any form of remuneration from a company.

Q41. How to structure employee participation in the start-up phase?

Prior to a financing round, employee participation can best be achieved by a transfer of shares within the founder team. After a financing round, employee participation causes a number of issues concerning taxes and structure (shares, options, corporate governance) and needs to be fine-tuned to each particular situation.

\section{Prepare Fund Raising}

Q42. How can additional shareholders be added?

The shareholders' group can be enlarged in two ways: Either by transferring existing shares or by issuing new ones. Any issuance of new shares to a new shareholder requires that current shareholders agree to waive their legal subscription right or that such subscription right is excluded by the shareholders' meeting for a valid reason.

\section{Q43. How to prepare for fund-raising?}

Most investors require a company limited by shares (AG/SA), an updated balance sheet and a clear situation regarding IP and contracts as well as an updated business plan. Furthermore, the founders need to know whether they are ready to accept typical private equity clauses (double-dip with or without founder carve-out, anti-dilution ratchet etc.) and therefore founders need to retain appropriate advisors.

Q44. Is crowd funding an option for start-up companies?

The public offering of shares without a prospectus is not lawful and may trigger 
personal liability of the founders. Most crowd funding platforms try to circumvent this restriction by offering participations in the form of loans or convertible loans. Accepting loans from a multitude of persons creates significant tax issues. Furthermore, such loans need to be clearly subordinated if the company wants to be able to spend the money. It remains to be seen if crowd funding will be able to circumvent these significant regulatory hurdles.

Q45. What does an investment agreement regulate?

An investment agreement is an agreement between an investor and a company and/or the company's founders. The agreement typically deals with the following issues:

a) Who subscribes for how many shares and at what price

b) Procedure for the capital increase

c) Representations and warranties regarding the business, IP, finances, etc.

d) Consequences in case of a breach of such representations and warranties

Typically the representations and warranties are given or at least guaranteed by the company's existing shareholders as any payments by the company for the breach of the representations and warranties are problematic. Furthermore, as a result of the respective payment for the investors, the company's value would further decrease which does not correspond to the investors' intentions. One way to circumvent this difficulty is to agree on a procedure to issue additional shares at nominal value to investors in case of a breach of representations and warranties. Alternatively, existing shareholders can indemnify the investors by way of cash payments which then are typically paid directly to the company.

\section{Q46. What is a cap table?}

A cap table or capitalization table shows the allocation of shares (divided into each class of share) for each founder and investor for each financing event together with the investment made in such round plus the total number of shares (number and percentage).

Q47. What does fully-diluted shareholding mean?

When shareholdings are expressed in percentages, then one can either exclude or include the conditional shares typi- cally reserved for employees (ESOP). If such future share grants are included, then the shareholding is shown fully-diluted. Professional investors and experienced business angels typically only look at the fully-diluted number.

\section{Q48. What does 'double-dip' mean?}

Professional investors (and experienced business angels) require that (1) their investment is paid back first in the case of an exit (sale of company etc.) and (2) after this pay-back, the remaining proceeds are distributed pro rata among all shareholders. Thus these professional investors dip into the proceeds twice. The rationale for this is that in the case of a limited return, the invested amount should be paid back first and that without such rule the pre-money valuation of the company would be much lower. One way to counter-balance this approach is to agree on a founder carve-out to be paid as a second category, such carveout reflecting the founders' non-cash contributions prior to the first financing.

Received: September 16, 2014

\section{Behind every start-up there is an innovative mind. As not every innovative mind is the mind of a born entrepreneur, the Federal Government, through the CTI, supports the development of new businesses, including those in the life sciences sector.

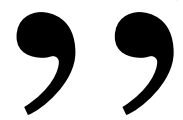

